\title{
The association between Toll-like receptor 2 single-nucleotide polymorphisms and hepatocellular carcinoma susceptibility
}

\author{
Xie Junjie $^{1 \dagger}$, Jiang Songyao ${ }^{2 \dagger}$, Shi Minmin², Song Yanyan ${ }^{3}$, Shen Baiyong ${ }^{1,2}$, Deng Xiaxing ${ }^{1,2}$, Jin Jiabin ${ }^{1,2}$,
} Zhan $\mathrm{Xi}^{1,2}$ and Chen Hao ${ }^{1,2,4^{*}}$

\begin{abstract}
Background: Toll-like receptors (TLR) are key innate immunity receptors participating in an immune response. Growing evidence suggests that mutations of TLR2/TLR9 gene are associated with the progress of cancers. The present study aimed to investigate the temporal relationship of single nucleotide polymorphisms (SNP) of TLR2/ TLR9 and the risk of hepatocellular carcinoma (HCC).

Methods: In this single center-based case-control study, SNaPshot method was used to genotype sequence variants of TLR2 and TLR9 in 211 patients with HCC and 232 subjects as controls.

Results: Two synonymous SNPs in the exon of TLR2 were closely associated with risk of HCC. Compared with those carrying wild-type homozygous genotypes (T/T), risk of HCC decreased significantly in individuals carrying the heterozygous genotypes (C/T) of the rs3804099 (adjusted odds ratio (OR), $0.493,95 \% \mathrm{Cl} 0.331-0.736, P<0.01$ ) and rs3804100 (adjusted OR, 0.509, 95\% Cl $0.342-0.759, P<0.01$ ). There was no significant association found in two TLR9 SNPs concerning the risk of HCC. The haplotype TT for TLR2 was associated significantly with the decreased risk of HCC (OR 0.524, 95\% Cl $0.394-0.697, P=0.000)$. Inversely, the risk of HCC increased significantly in patients with the haplotype CC (OR 2.743, 95\% Cl $1.915-3.930, P=0.000)$.

Conclusions: These results suggested that TLR2 rs3804099 C/T and rs3804100 C/T polymorphisms were closely associated with HCC. In addition, the haplotypes composed of these two TLR2 synonymous SNPs have stronger effects on the susceptibility of HCC.
\end{abstract}

\section{Background}

Toll-like receptors (TLRs) belong to a family of transmembrane receptors that play a key role in immune response against microbial pathogens by recognizing specific microbial molecular components. After activated, TLRs initiate a signaling cascade resulting in the stimulation of innate and adaptive immune responses targeting the invading pathogen [1].

There are some evidences showing potential association between the activation of TLR2/TLR9 and carcinogenesis. Lipopolysaccharide induces the production of transforming growth factor-beta and hepatocyte growth

\footnotetext{
* Correspondence: haochendr@yahoo.com.cn

+ Contributed equally

'Department of Surgery, Ruijin Hospital, Shanghai Jiao Tong University

School of Medicine, Shanghai, P.R. China

Full list of author information is available at the end of the article
}

factor mediated by CD14/TLR2 in cultured human colon cancer cell lines [2]. Listeria monocytogenes could activate mitogen-activated protein kinases and nuclear factor-kappaB in tumor cells, resulting in the increased production of nitric oxide and interleukin-6 and enhanced proliferation of tumor cells. All of these effects could be abrogated by silencing expression of TLR2 [3].

TLR signals exist in hepatitis $B$, hepatitis $C$, alcoholic liver disease, non-alcoholic liver diseases, primary biliary cirrhosis, primary sclerosing cholangitis, hepatic fibrosis, ischemic-reperfusion injury and liver allograft rejection [4]. TLRs can be expressed by various cell types in the liver. Kupffer cells express TLR2 and TLR9. And hepatocytes and biliary epithelium express TLR2 while stellate cells express TLR9 [4]. TLR2 is downregulated in

\section{C) Biomed Central}


hepatocytes, Kupffer cells and peripheral blood monocytes in hepatitis-B-antigen-positive patients [5]. In hepatitis-B-e-antigen-negative patients, TLR2 expression and tumor necrosis factor- $\alpha$ production is up-regulated and probably mediated by precore proteins [5]. In vitro, HBV replication could be inhibited by stimulating IL-1 receptor and TLR2 receptors and subsequently activation of a signaling cascade in hepatoma cell lines [6]. In a chemical-induced mouse model developed by Oliva et al. [7], it was shown that tumorigenesis in liver was associated with TLR2 activation. The expression of TLR 9 (CpG-specific) was also found in some hepatoma cell lines such as HepG2, HuH7, and Hep3B. CpG DNA of HBV DNA may contribute to the malignant transformation of benign liver cells [8]. Cell surface stimulation of TLR9 promoted cell proliferation and survival in HCC cell lines [9]. In patients with chronic HBV, TLR9 expression on peripheral blood mononuclear cells was related to HCC [10]. There is growing evidence showing the impact of TLR2 and TLR9 genetic polymorphisms on risk of gallbladder cancer [11], cervical cancer [12], non-Hodgkin lymphoma [13] and endometrial cancer [14].

Based on the information above, we hypothesized that single nucleotide polymorphisms of TLR2 and TLR9 may be related to the occurrence of HCC. To test this hypothesis, a systematic genetic analysis was performed in a Chinese population hospital-based HCC case-control study.

\section{Methods \\ Study design}

The data for total 20 TLR2 and 9 TLR9 SNPs genotyped in Chinese (CHD) people population from the database of the International HapMap project http://hapmap. ncbi.nlm.nih.gov/index.html.zh. Fifteen TLR2 SNPs and seven TLR9 SNPs were of minor allele frequencies (MAF) $<5 \%$ and were eliminated from subsequent analysis. The remaining 5 TLR2 SNPs were evaluated: two synonymous SNPs in the single exon of the gene (rs3804099, rs3804100) and three SNPs in intron (rs11938228, rs769632 and rs1898830). Two TLR9 SNPs were located in intron (rs352139) and exon (rs352140). Haplotype was analyzed by using a limited number of TLRs SNPs.

\section{Study samples}

We analyzed 211 patients with HCC and 232 non malignant subjects in this case-control study in Ruijin Hospital, Shanghai Jiao Tong University School of Medicine. The ethnic backgrounds of subjects were all Chinese. HCC was diagnosed by the elevation of alphafetoprotein (> $400 \mathrm{ng} / \mathrm{ml}$ ) or by pathological examination in combination with the results of examination of iconography including computer tomography or magnetic resonance imaging and proved to be without bearing any other cancers. Clinical classification was according to International Union Against Cancer (UICC) tumor-node-metastasis (TNM) staging system [15]. For the severity of liver disease, Child-Pugh score was evaluated between two groups.

HBV carriers were defined as positive for both hepatitis $B$ surface antigen and immunoglobulin $G$ against hepatitis $\mathrm{B}$ core antigen. The treatments for HCC patients were hepatectomy, liver transplantation, chemotherapy and transcatheter arterial chemoembolization. In order to eliminate the confounding effect of $\mathrm{HBV}$ infection in research of genetic susceptibility to $\mathrm{HCC}$, controls were randomly selected from the individuals who attended hepatitis examination in the hospital during the period of case collection. The selection criteria for the control subjects included no medical history of any cancer at the time of ascertainment and frequency matching to the patients on age and gender. All subjects provided informed consent in this study. The study protocol was approved by the independent ethics committee of Ruijin Hospital, Shanghai Jiao Tong University Medical School.

\section{Genotyping}

Genomic DNA was extracted from peripheral blood leukocytes. The genomic regions of interest were amplified by multiplex polymerase chain reactions (PCRs). The PCR reactions were performed and all 7 SNPs were genotyped by $\mathrm{SNaPshot}$ method according to our previous protocol [16].

Genotype analysis was performed in a blinded manner so that staff was unaware of the cases or control status. For quality control, a 10\% masked random sample of cases and controls was tested repetitively by different investigators and all the results were completely concordant.

\section{Statistical analysis}

Data were expressed as proportions, mean and standard deviation (SD) or medians (range). All these tests were performed with the SPSS 13.0 version for Windows. All reported $P$ values were two sided. Grouped data were compared by the Mann-Whitney $U$ test.

The Hardy-Weinberg equilibrium (HWE) test using $\chi^{2}$ analysis was done for each SNP among cases and controls. Genotype frequency differences were tested between HCC patients and control subjects were tested for each SNP by the $\chi^{2}$ test with 2 degrees of freedom.

Odds ratios (ORs) of HCC for the variant-allele carriers (homozygous and heterozygous) versus homozygous wild-type allele carriers were estimated by unconditional logistic regression and adjusted for sex and age $(<=55$ or $>55)$. 
Haplotype block structure and the estimates of pairwise linkage disequilibrium (LD) (D') were determined by using Haploview software http://www.broadinstitute. org/scientific-community/science/programs/medicaland-population-genetics/haploview/haploview. The LD patterns from HapMap CHD population were evaluated to avoid SNPs in strong LD $\left(\mathrm{r}^{2}>=0.8\right)$. Haplotype frequency was estimated with the statistical method by implementing the computer program PHASE. A global score test was used to assess the difference in haplotype frequency distributions between cases and controls. Association between the haplotypes and HCC was performed with the $\chi^{2}$ test.

False-positive report probabilities (FPRPs) for the significant results $(P<0.05)$ were calculated to account for potential false positives. FPRP is defined as the probability of no true association between genetic variants and disease given the statistically significant finding. The values of FPRP were assessed by using the method described by Wacholder et al. [17]. The FPRP was determined by: the prior probability of a true association, observed $P$ value and statistical power. Moderate-high prior probabilities of $0.10-0.25$ were assigned and a significant finding with a FPRP $<0.50$ was considered.

\section{Results}

The clinical characteristics of HCC patients and control subjects were summarized in Table 1 and no significant differences were observed in age, sex, Child-Pugh score and HBV carriers between two groups $(P>0.05)$.

In both HCC patients and control group, the genotypes of selected polymorphisms of TLR2 and TLR9 were in Hardy-Weinberg equilibrium, with no significant $\chi^{2}$ values $(P>0.05)$ except for rs3804099 and rs3804100 in control group $(P=0.012)$. Although

Table 1 Main demographic and clinical characteristics of the studied population

\begin{tabular}{|c|c|c|c|}
\hline Characteristics & $\begin{array}{l}\mathrm{HCC} \\
n=211\end{array}$ & $\begin{array}{l}\text { Controls } \\
n=232\end{array}$ & $P$ values \\
\hline Age, year ${ }^{a}$ & $53.87(18-90)$ & $47.07(22-90)$ & 0.309 \\
\hline Male gender, n (\%) & $178(84.36 \%)$ & $187(80.6 \%)$ & 0.300 \\
\hline HBV carriers, n (\%) & $172(81.52 \%)$ & $184(79.3 \%)$ & 0.559 \\
\hline Child-Pugh score & & & 0.202 \\
\hline A & $185(87.68 \%)$ & $212(91.38 \%)$ & \\
\hline B & $26(12.32 \%)$ & $20(8.62 \%)$ & \\
\hline \multicolumn{4}{|l|}{$\alpha$-FP level } \\
\hline$>400 \mathrm{ng} / \mathrm{ml}, \mathrm{n}(\%)$ & 78 (36.97\%) & & \\
\hline$<400$ ng/ml, n (\%) & $133(63.03 \%)$ & & \\
\hline \multicolumn{4}{|l|}{ UICC classification } \\
\hline Stage I-II, n (\%) & $98(46.45 \%)$ & & \\
\hline Stage III-IV, n (\%) & $113(53.55 \%)$ & & \\
\hline
\end{tabular}

${ }^{\mathrm{a}}$ Median (range) rs3804099 and rs3804100 were deviated from HardyWeinberg equilibrium, we still retained them in the analyses as these $P$ values were marginal and may be chance findings and the internal blinded quality-control specimens did not show evidence of genotyping error.

The two TLR2 polymorphisms were in high LD (rs1898830 + rs11938228 and rs3804099 + rs3804100, D' > 0.9) (see Figure 1).

The genotype frequencies were compared between the patients and controls for the polymorphisms in TLR2 and TLR9 (see Table 2). Only two TLR2 polymorphisms (rs3804099 and rs3804100) showed significantly different distributions between HCC patients and the controls ( $P$ $<0.05$ ) (see Table 2). No different distribution between HCC patients and the controls was observed in TLR9 SNPs.

Carriers of the C/T of rs3804099 and rs3804100 of TLR2 had a nominally significant association with decreased HCC risk (OR 0.493, 95\% CI 0.331 - 0.736; OR $0.509,95 \%$ CI $0.342-0.759)$ by age and sex adjustment $(P<0.01)$ (see Table 3$)$ compared with $\mathrm{T} / \mathrm{T}$ carriers. No significant association was found in TLR9 polymorphisms with the risk of HCC. Furthermore, we evaluated the effect of TLR2 and TLR9 SNPs for $\alpha$-FP level and UICC pathologic stage in patients with HCC (see Table 4) and found that no SNP had any influence on these two factors.

The haplotype analysis was performed to evaluate the frequencies of haplotypes based on the two polymorphisms within the block 2 of TLR2. The haplotype TT was associated significantly with the decrease of the risk of HCC (OR 0.524, 95\% CI 0.394 - 0.697, $P=0.000$ ). Inversely, the risk of $\mathrm{HCC}$ increased significantly in patients with the haplotype CC (OR 2.743, 95\% CI 1.915 - 3.930, $P=0.000$ ) (see Table 5).

The association for two TLR2 polymorphisms and two TLR2 haplotypes showed a FPRP below 0.200, which suggested that these associations are unlikely to represent a false-positive result (see Table 6).

\section{Discussion}

The relationship between TLR2 polymorphisms and the progresses of tumors have been explored and reported by some researchers. Boraska Jelavić et al. [18] reported an association of TLR2 GT microsatelite alleles with 20 and $21 \mathrm{GT}$ repeats with sporadic colorectal cancer among Croatians. In the study by Srivastava et al. [19], del allele carriers of TLR2 (Delta22) polymorphism were associated with a 1.54-fold increased risk for gallbladder cancer. In another study by Pandey et al. [12], TLR 2 gene polymorphisms (-196 to $-174 \mathrm{del})$ showed significant association (OR 1.6, 95\% CI 1.00-2.51) with cervical cancer susceptibility. Similarly, it was also confirmed in the study by Nischalke et al. [20] that the frequency of 


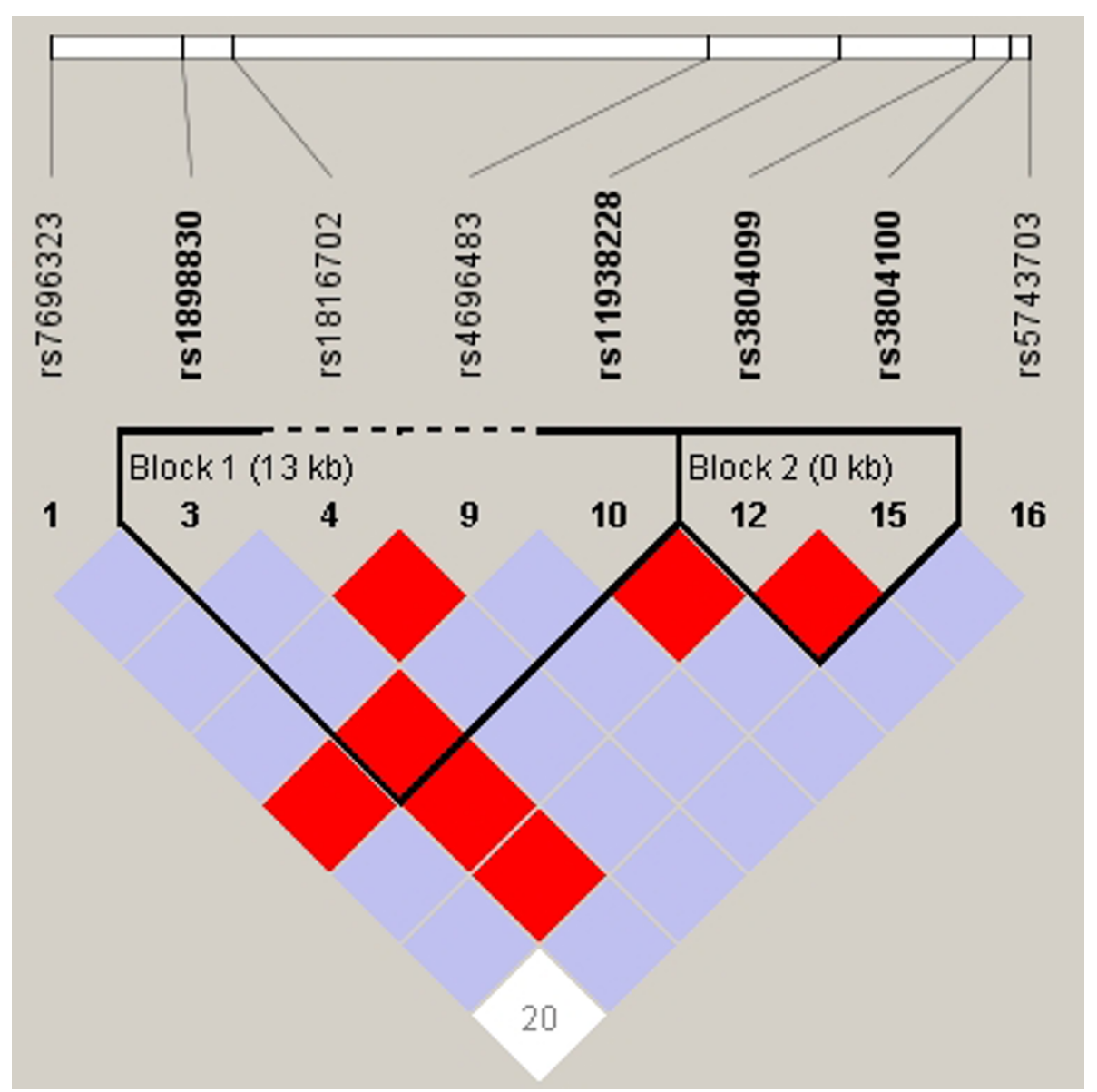

Figure 1 Linkage disequilibrium plot of TLR2 SNPs in patients with HCC. D' corresponding to each SNP pair are expressed as a percentage and shown within the respective square. Higher $D^{\prime}$ is indicated by a brighter red.

the TLR2 -196 to -174del allele was significantly higher in cases with $\mathrm{HCV}$-associated HCC than in $\mathrm{HCV}$ infected patients without HCC. And in carriers of the TLR2 -196 to -174del allele stimulation of monocytes resulted in significantly lower TLR2 expression levels and IL- 8 induction than in individuals with the TLR2 -196 to -174 ins/ins genotype. The current study was the first one to show that inherited variation in TLR2 influences the risk of HCC. We observed the positive association between two SNPs in exon (rs3804099 and rs3804100) and the risk of HCC. The risk of HCC was found to be significantly low in individuals carrying the heterozygous genotypes of these two SNPs by comparing with those carrying wild-type homozygous genotypes (OR, from 0.331 to $0.759, P<0.001$ ). Our data suggested that TLR2 gene variation may play an important protective role in the occurrence of HCC. Though the observed two-fold decrease in risk is modest, our finding is intriguing because genes in multiple pathways alter the risk for $\mathrm{HCC}$, and each individual gene is likely to contribute only a modest risk. rs3804099 and rs3804100 of TLR2 are synonymous SNPs. It has long been assumed that synonymous SNPs are inconsequential, as they do not lead to a change in primary polypeptide sequence. However, over the last decade, it has been confirmed in many studies that synonymous mutations are implicated in diseases. Several mechanisms by which synonymous mutations exert their impact on gene function are: (1) Perturbations of mRNA splicing. Ectopic mRNA splicing generated by synonymous SNPs can bring about distinct phenotypes, leading to human disease [21]. Synonymous base pair changes in auxiliary elements within exons (exonic splicing enhancers and exonic splicing silencers) can directly change the splicing patterns of mRNA transcripts, or they can alter the penetrance of concurring mutations elsewhere in the gene [22,23]. (2) The stability of mRNA. Synonymous SNPs can affect the stability of mRNA via cis factors which determine mRNA stability fall within the 3'-untranslated region of a transcript [24]. (3) mRNA structure. Synonymous SNPs can modulate mRNA structure and have downstream effects on 
Table 2 Genotype distribution of TLR2 and TLR9 SNPs in HCC patients and controls

\begin{tabular}{|c|c|c|c|c|c|c|}
\hline & SNP & Location & Genotype & $\mathrm{HCC}$ & Control & $P$ values \\
\hline \multirow[t]{15}{*}{ TLR2 } & rs7696323 & intron & $C / C$ & 109 & 125 & 0.239 \\
\hline & & & $C / T$ & 80 & 93 & \\
\hline & & & $\mathrm{T} / \mathrm{T}$ & 22 & 14 & \\
\hline & rs1898830 & intron & $\mathrm{G} / \mathrm{G}$ & 72 & 80 & 0.093 \\
\hline & & & $A / G$ & 92 & 118 & \\
\hline & & & $\mathrm{A} / \mathrm{A}$ & 47 & 34 & \\
\hline & rs11938228 & intron & A/A & 78 & 84 & 0.211 \\
\hline & & & $\mathrm{A} / \mathrm{C}$ & 89 & 113 & \\
\hline & & & $\mathrm{C} / \mathrm{C}$ & 44 & 35 & \\
\hline & rs3804099 & cds-synon & $\mathrm{C} / \mathrm{C}$ & 121 & 100 & 0.002 \\
\hline & & & $\mathrm{C} / \mathrm{T}$ & 71 & 117 & \\
\hline & & & $T / T$ & 19 & 15 & \\
\hline & rs3804100 & cds-synon & $\mathrm{C} / \mathrm{C}$ & 130 & 111 & 0.003 \\
\hline & & & $\mathrm{C} / \mathrm{T}$ & 67 & 110 & \\
\hline & & & $T / T$ & 14 & 11 & \\
\hline \multirow[t]{6}{*}{ TLR9 } & rs352140 & cds-synon & $\mathrm{C} / \mathrm{C}$ & 96 & 102 & 0.153 \\
\hline & & & $C / T$ & 85 & 109 & \\
\hline & & & $\mathrm{T} / \mathrm{T}$ & 30 & 21 & \\
\hline & rs352139 & intron & $\mathrm{A} / \mathrm{A}$ & 82 & 101 & 0.362 \\
\hline & & & $\mathrm{G} / \mathrm{A}$ & 102 & 110 & \\
\hline & & & $\mathrm{G} / \mathrm{G}$ & 27 & 21 & \\
\hline
\end{tabular}

$P$ value was calculated by a $\chi^{2}$-test $3 \times 2$ contingency table $(\mathrm{df}=2)$ protein expression and phenotype [25]. (4) Protein folding. It has been confirmed by some computational and experimental studies $[26,27]$ that synonymous SNPs have an influence on protein folding and ultimately protein function. Which mechanism by these synonymous SNPs impact should be investigated in future research.

In the present study, LD analysis showed that these two TLR2 synonymous SNPs were in high LD and located in one haplotype block. Individuals carrying haplotype TT was significantly associated with the decrease of the risk of HCC (OR 0.524, 95\% CI 0.394 - 0.697, $P=$ $0.000)$. Inversely, the risk of HCC significantly increased in patients carrying haplotype CC (OR 2.743, 95\% CI $1.915-3.930, P=0.000)$. In a recent study by Diatchenko et al. [28], it was shown that the low pain sensitivity (LPS) haplotype composed of synonymous SNPs produces much higher levels of the cathechol-O-methyltransferase (COMT) enzymatic activity when compared with the average pain sensitivity (APS) or high pain sensitivity (HPS) haplotypes. The variation in COMT expression levels among haplotypes was due to the differences in protein translation efficiency, which marks the final manner in which synonymous SNPs can exert their influence on protein translation and cotranslational protein folding. Hunt et al. [24] suggested that

Table 3 Association between hepatocellular carcinoma and TLR2 and TLR9 SNPs

\begin{tabular}{|c|c|c|c|c|c|c|}
\hline Gene & SNP & Genotype & Odds Ratio $(95 \% \mathrm{Cl})$ & $P$ Value & Odds Ratio $(95 \% \mathrm{Cl}) \dagger$ & $P$ Value \\
\hline \multirow[t]{15}{*}{ TLR2 } & rs7696323 & $\mathrm{C} / \mathrm{C}$ & 1 & & 1 & \\
\hline & & $\mathrm{C} / \mathrm{T}$ & $1.014(0.684-1.503)$ & 0.946 & $1.001(0.673-1.489)$ & 0.995 \\
\hline & & $\mathrm{T} / \mathrm{T}$ & $0.555(0.271-1.137)$ & 0.108 & $0.560(0.271-1.157)$ & 0.118 \\
\hline & rs1898830 & $\mathrm{A} / \mathrm{A}$ & 1 & & 1 & \\
\hline & & $A / G$ & $0.866(0.570-1.317)$ & 0.502 & $0.902(0.591-1.378)$ & 0.634 \\
\hline & & $\mathrm{G} / \mathrm{G}$ & $1.536(0.891-2.647)$ & 0.122 & $1.531(0.885-2.649)$ & 0.128 \\
\hline & rs11938228 & $\mathrm{C} / \mathrm{C}$ & 1 & & 1 & \\
\hline & & $\mathrm{A} / \mathrm{C}$ & $0.848(0.560-1.284)$ & 0.437 & $0.884(0.582-1.344)$ & 0.565 \\
\hline & & $\mathrm{A} / \mathrm{A}$ & $1.354(0.789-2.324)$ & 0.272 & $1.340(0.777-2.309)$ & 0.292 \\
\hline & rs3804099 & $T / T$ & 1 & & 1 & \\
\hline & & $\mathrm{C} / \mathrm{T}$ & $0.502(0.337-0.745)$ & 0.001 & $0.493(0.331-0.736)$ & 0.001 \\
\hline & & $\mathrm{C} / \mathrm{C}$ & $1.047(0.506-2.166)$ & 0.902 & $1.048(0.503-2.182)$ & 0.901 \\
\hline & rs3804100 & $\mathrm{T} / \mathrm{T}$ & 1 & & 1 & \\
\hline & & $\mathrm{C} / \mathrm{T}$ & $0.520(0.350-0.772)$ & 0.001 & $0.509(0.342-0.759)$ & 0.001 \\
\hline & & $\mathrm{C} / \mathrm{C}$ & $1.087(0.474-2.490)$ & 0.844 & $0.844(0.441-2.358)$ & 0.964 \\
\hline \multirow[t]{6}{*}{ TLR9 } & rs352140 & $\mathrm{C} / \mathrm{C}$ & 1 & & 1 & \\
\hline & & $C / T$ & $0.829(0.557-1.233)$ & 0.354 & $0.861(0.576-1.286)$ & 0.464 \\
\hline & & $\mathrm{T} / \mathrm{T}$ & $1.518(0.814-2.831)$ & 0.19 & $1.438(0.767-2.695)$ & 0.258 \\
\hline & rs352139 & $\mathrm{G} / \mathrm{G}$ & 1 & & 1 & \\
\hline & & $\mathrm{G} / \mathrm{A}$ & $1.142(0.768-1.698)$ & 0.512 & $1.180(0.790-1.761)$ & 0.419 \\
\hline & & $\mathrm{A} / \mathrm{A}$ & $1.584(0.835-3.004)$ & 0.159 & $1.521(0.798-2.900)$ & 0.202 \\
\hline
\end{tabular}

† Adjusted for age and sex. $P$ value was calculated by a $\chi^{2}$-test $2 \times 2$ contingency table $(\mathrm{df}=1)$ 
Table 4 Effect of TLR2 and TLR9 SNPs for $\alpha$-FP level and UICC pathologic stage in patients with hepatocellular carcinoma

\begin{tabular}{|c|c|c|c|c|c|c|}
\hline Gene & SNP & Genotype & Odds Ratio $(95 \% \mathrm{Cl})+$ & $P$ Value & Odds Ratio $(95 \% \mathrm{Cl}) \neq$ & $P$ Value \\
\hline \multirow[t]{15}{*}{ TLR2 } & rs7696323 & $\mathrm{C} / \mathrm{C}$ & 1 & & 1 & \\
\hline & & $C / T$ & $0.623(0.339-1.142)$ & 0.126 & $0.703(0.393-1.257)$ & 0.235 \\
\hline & & $\mathrm{T} / \mathrm{T}$ & $0.639(0.241-1.693)$ & 0.368 & $0.402(0.156-1.038)$ & 0.060 \\
\hline & rs1898830 & $\mathrm{A} / \mathrm{A}$ & 1 & & 1 & \\
\hline & & $A / G$ & $0.491(0.771-2.885)$ & 0.235 & $1.434(0.740-2.635)$ & 0.237 \\
\hline & & $\mathrm{G} / \mathrm{G}$ & $2.137(0.994-4.597)$ & 0.052 & $1.304(0.624-2.726)$ & 0.480 \\
\hline & rs11938228 & $C / C$ & 1 & & 1 & \\
\hline & & $A / C$ & $1.702(0.894-3.239)$ & 0.106 & $1.421(0.771-2.616)$ & 0.260 \\
\hline & & $\mathrm{A} / \mathrm{A}$ & $1.656(0.764-3.587)$ & 0.201 & $1.458(0.693-3.479)$ & 0.590 \\
\hline & rs3804099 & $\mathrm{T} / \mathrm{T}$ & 1 & & 1 & \\
\hline & & $C / T$ & $1.140(0.623-2.083)$ & 0.671 & $1.160(0.644-2.088)$ & 0.621 \\
\hline & & $\mathrm{C} / \mathrm{C}$ & $0.808(0.287-2.276)$ & 0.686 & $1.308(0.492-3.479)$ & 0.590 \\
\hline & rs3804100 & $T / T$ & 1 & & 1 & \\
\hline & & $C / T$ & $1.192(0.651-2.183)$ & 0.569 & $1.232(0.681-2.230)$ & 0.490 \\
\hline & & $\mathrm{C} / \mathrm{C}$ & $0.706(0.210-2.377)$ & 0.575 & $0.940(0.312-2.832)$ & 0.913 \\
\hline \multirow[t]{6}{*}{ TLR9 } & rs352140 & $C / C$ & 1 & & 1 & \\
\hline & & $C / T$ & $0.928(0.511-1.685)$ & 0.805 & $0.875(0.487-1.573)$ & 0.655 \\
\hline & & $\mathrm{T} / \mathrm{T}$ & $0.465(0.137-1.076)$ & 0.054 & $0.595(0.260-1.360)$ & 0.218 \\
\hline & rs352139 & $\mathrm{G} / \mathrm{G}$ & 1 & & 1 & \\
\hline & & $\mathrm{G} / \mathrm{A}$ & $1.106(0.609-2.008)$ & 0.741 & $1.051(0.587-1.884)$ & 0.866 \\
\hline & & $\mathrm{A} / \mathrm{A}$ & $0.470(0.171-1.292)$ & 0.143 & $0.691(0.288-1.656)$ & 0.407 \\
\hline
\end{tabular}

† $\alpha$-FP level: $>400 \mathrm{ng} / \mathrm{ml}$ or $<=400 \mathrm{ng} / \mathrm{ml}$

\# UICC classification: stage I, II or stage III, IV

haplotypes composed of synonymous SNPs can have profound effects on gene function, and in some cases their effects can be stronger than those of their nonsynonymous counterparts.

Few investigations have been reported about the relationship between TLR9 polymorphisms and the tumor susceptivity. In the study by Ashton et al. [14], haplotype analysis showed that the combination of the variant alleles of the two TLR9 polymorphisms, rs5743836 and rs187084, were protective in endometrial cancer (OR $0.11,95 \%$ CI $0.03-0.44)$. In a case-control study by Etokebe et al. [29], TLR9 (c.1635A > G) polymorphisms were not likely to be a risk factor in developing breast

Table 5 Association of haplotypes in TLR2 with HCC

\begin{tabular}{lllll}
\hline Haplotype & Control & Case & OR $(\mathbf{9 5 \%} \mathrm{Cl})$ & $\begin{array}{l}\boldsymbol{P} \\
\text { Value }\end{array}$ \\
& Frequencyt & Frequencyt & \\
\hline Block 2 & & & & \\
TT & $\mathbf{0 . 5 8 5 9 3 8}$ & $\mathbf{0 . 7 2 9 7 4 8}$ & $\mathbf{0 . 5 2 4}(\mathbf{0 . 3 9 4 -}$ & $\mathbf{0 . 0 0 0}$ \\
& & & $\mathbf{0 . 6 9 7})$ & \\
TC & 0.067079 & 0.080679 & $0.779(0.457-1.329)$ & 0.359 \\
CT & 0.086476 & 0.078309 & $1.099(0.664-1.818)$ & 0.713 \\
CC & $\mathbf{0 . 2 6 0 5 0 7}$ & $\mathbf{0 . 1 1 1 2 6 4}$ & $\mathbf{2 . 7 4 3 ( 1 . 9 1 5 -}$ & $\mathbf{0 . 0 0 0}$ \\
& & & $\mathbf{3 . 9 3 0 )}$ &
\end{tabular}

$\uparrow$, proportion of indicated haplotype (\%). $P$ value was calculated by a $\chi^{2}$-test 2 $\times 2$ contingency table $(\mathrm{df}=1)$. cancer. Although Hold et al. [30] found TLR9 (TLR9$1237 \mathrm{~T} / \mathrm{C}$, rs574383) was associated with the development of premalignant gastric lesions in 2006, but their most recent study showed that this SNP didn't increase the risk of gastric cancer itself [31]. Similarly, we didn't find any relationship between two TLR9 genetic variations and the occurrence of HCC.

Recently, Zhang and colleagues [32] conducted a genome-wide association study by genotyping 440,794 SNPs in 355 chronic HBV carriers with HCC and 360 chronic HBV carriers without HCC in Chinese population using

Table 6 FPRPs for the selected associations between genetic polymorphisms and HCC

\begin{tabular}{|c|c|c|c|c|c|c|}
\hline \multirow{2}{*}{$\begin{array}{l}\text { SNP or } \\
\text { Haplotype }\end{array}$} & \multirow{2}{*}{$\begin{array}{l}\text { OR } \\
(95 \% \mathrm{Cl})\end{array}$} & \multirow{2}{*}{$\begin{array}{l}\text { Observed } \\
P \text { value }\end{array}$} & \multicolumn{4}{|c|}{ Prior probability } \\
\hline & & & 0.25 & 0.1 & 0.01 & 0.001 \\
\hline \multicolumn{7}{|l|}{ SNP } \\
\hline rs3804099 & $\begin{array}{l}0.493 z(0.331 \\
-0.736)\end{array}$ & 0.001 & 0.023 & 0.065 & 0.434 & 0.886 \\
\hline rs3804100 & $\begin{array}{l}0.509(0.342- \\
0.759)\end{array}$ & 0.001 & 0.029 & 0.082 & 0.497 & 0.909 \\
\hline \multicolumn{7}{|c|}{ Haplotype (Block 2) } \\
\hline$\Pi$ & $\begin{array}{l}0.524(0.394- \\
0.697)\end{array}$ & 0.000 & 0.001 & 0.002 & 0.018 & 0.155 \\
\hline CC & $\begin{array}{l}2.743(1.915- \\
3.930)\end{array}$ & 0.000 & 0.001 & 0.002 & 0.018 & 0.155 \\
\hline
\end{tabular}


Affymetrix Genome-Wide Human SNP Array 5.0. In this study, one intronic SNP (rs17401966) in KIF1B on chromosome 1p36.22 was highly associated with HBVrelated HCC. However, only rs11938228 and rs10759930 of TLR2 and rs1927911 of TLR9 were enrolled in Affymetrix Genome-Wide Human SNP Array 5.0 chip and these three SNPs were not related to HCC. In our study, only TLR2 rs11938228 was determined and our result was consistent to them, that TLR2 rs11938228 was not associated with the risk of HCC.

Although SNP rs3804099 and rs3804100 were out of HWE $(P=0.01-0.02)$, we retained them in the analyses as these $P$ values were marginal and may be chance findings and the internal blinded quality-control specimens did not show evidence of genotyping error. These two SNPs genotyped were deviated HWE in the controls but not in the cases. The association for these two polymorphisms showed a FPRP below 0.200. It suggested strongly that these associations are unlikely to represent a false-positive result. Considering these two SNPs showed any evidence of deviation in cases, it was not believed that the marginal HWE tests in controls suggest systematic genotyping errors.

\section{Conclusions}

TLR2 rs3804099 C/T and rs3804100 C/T polymorphisms were associated closely with HCC. In addition, the haplotypes composed of these two synonymous SNPs have profound effects on the susceptibility of HCC.

\section{Acknowledgements}

This work was funded by Major Foundation of Science and Technology Commission of Shanghai Municipality (No: 09411952200) and National Natural Science Foundation (81070356). The authors thank Dr Pan Chunming for his help in the analysis of SNP; Dr Lu Hui for his help in revision of the manuscript.

\section{Author details}

'Department of Surgery, Ruijin Hospital, Shanghai Jiao Tong University School of Medicine, Shanghai, P.R. China. ${ }^{2}$ Research Institute of Digestive Surgery, Ruijin Hospital, Shanghai Jiao Tong University School of Medicine, Shanghai, P.R. China. ${ }^{3}$ Department of Pharmacology and Biostatistics, Institute of Medical Sciences, Shanghai Jiao Tong University School of Medicine, Shanghai, P.R. China. ${ }^{4}$ Department of Surgery and Research Institute of Digestive Surgery, Ruijin Hospital, Shanghai Jiao Tong University School of Medicine, Shanghai, P.R. China.

\begin{abstract}
Authors' contributions
$\mathrm{XJ}$ and JS carried out the genotyping analysis, and drafted the manuscript. SM participated the collection of clinical materials. SY performed the statistical analysis. SB, DX participated in the design of the study. JJ and ZX helped to draft the manuscript. $\mathrm{CH}$ designed the study, participated the analysis of the results and drafted the manuscript. All authors read and approved the final manuscript.
\end{abstract}

\section{Competing interests}

The authors declare that they have no competing interests.

Received: 15 September 2011 Accepted: 7 February 2012 Published: 7 February 2012
References

1. Andreakos E, Foxwell B, Feldmann M: Is targeting Toll-like receptors and their signaling pathway a useful therapeutic approach to modulating cytokine-driven inflammation? Immunol Rev 2004, 202:250-265.

2. Yoshioka T, Morimoto Y, Iwagaki H, Itoh H, Saito S, Kobayashi N, Yagi T, Tanaka N: Bacterial lipopolysaccharide induces transforming growth factor beta and hepatocyte growth factor through toll-like receptor 2 in cultured human colon cancer cells. J Int Med Res 2001, 29:409-420.

3. Huang B, Zhao J, Shen S, Li H, He KL, Shen GX, Mayer L, Unkeless J, Li D, Yuan Y, Zhang GM, Xiong H, Feng ZH: Listeria monocytogenes promotes tumor growth via tumor cell toll-like receptor 2 signaling. Cancer Res 2007, 67:4346-4352.

4. Testro AG, Visvanathan $\mathrm{K}$ : Toll-like receptors and their role in gastrointestinal disease. J Gastroenterol Hepatol 2009, 24:943-954

5. French SW, Oliva J, French BA, Li J, Bardag-Gorce F: Alcohol, nutrition and liver cancer: role of Toll-like receptor signaling. World J Gastroenterol 2010, 16:1344-1348.

6. Thompson AJ, Colledge D, Rodgers S, Wilson R, Revill P, Desmond P, Mansell A, Visvanathan K, Locarnini S: Stimulation of the interleukin-1 receptor and Toll-like receptor 2 inhibits hepatitis $B$ virus replication in hepatoma cell lines in vitro. Antivir Ther 2009, 14:797-808.

7. Oliva J, Bardag-Gorce F, French BA, Li J, McPhaul L, Amidi F, Dedes J, Habibi A, Nguyen S, French SW: Fat10 is an epigenetic marker for liver preneoplasia in a drug-primed mouse model of tumorigenesis. Exp Mol Pathol 2008, 84:102-112.

8. Liu X, Xu Q, Chen W, Cao H, Zheng R, Li G: Hepatitis B virus DNA-induced carcinogenesis of human normal liver cells by virtue of nonmethylated CpG DNA. Oncol Rep 2009, 21:941-947.

9. Tanaka J, Sugimoto K, Shiraki K, Tameda M, Kusagawa S, Nojiri K, Beppu T, Yoneda K, Yamamoto N, Uchida K, Kojima T, Takei Y: Functional cell surface expression of toll-like receptor 9 promotes cell proliferation and survival in human hepatocellular carcinomas. Int J Oncol 2010, 37:805-814.

10. $\mathrm{Xu} \mathrm{N}$, Yao HP, Sun Z, Chen Z: Toll-like receptor 7 and 9 expression in peripheral blood mononuclear cells from patients with chronic hepatitis B and related hepatocellular carcinoma. Acta Pharmacol Sin 2008, 29:239-244.

11. Srivastava K, Srivastava A, Kumar A, Mittal B: Gallbladder cancer predisposition: a multigenic approach to DNA-repair, apoptotic and inflammatory pathway genes. PLoS One 2011, 6:e16449.

12. Pandey $S$, Mittal RD, Srivastava M, Srivastava $K$, Singh $S$, Srivastava $S$, Mittal B: Impact of Toll-like receptors [TLR] 2 (-196 to -174 del) and TLR 4 (Asp299Gly, Thr399lle) in cervical cancer susceptibility in North Indian women. Gynecol Oncol 2009, 114:501-505.

13. Purdue MP, Lan Q, Wang SS, Kricker A, Menashe I, Zheng TZ, Hartge P, Grulich AE, Zhang Y, Morton LM, Vajdic CM, Holford TR, Severson RK, Leaderer BP, Cerhan JR, Yeager M, Cozen W, Jacobs K, Davis S, Rothman N, Chanock SJ, Chatterjee N, Armstrong BK: A pooled investigation of Tolllike receptor gene variants and risk of non-Hodgkin lymphoma. Carcinogenesis 2009, 30:275-281.

14. Ashton KA, Proietto A, Otton G, Symonds I, McEvoy M, Attia J, Scott RJ: Toll-like receptor (TLR) and nucleosome-binding oligomerization domain (NOD) gene polymorphisms and endometrial cancer risk. BMC Cancer 2010, 10:382.

15. Greene FL: AJCC cancer staging manual Chicago: Springer; 2002, 435

16. Minmin S, Xiaogian X, Hao C, Baiyong S, Xiaxing D, Junjie X, Xi Z, Jianquan $Z$, Songyao J: Single nucleotide polymorphisms of toll-like receptor 4 decrease the risk of development of hepatocellular carcinoma. PLoS One 2011, 6:e19466

17. Wacholder S, Chanock S, Garcia-Closas M, El Ghormli L, Rothman N: Assessing the probability that a positive report is false: an approach for molecular epidemiology studies. J Natl Cancer Inst 2004, 96:434-442.

18. Boraska Jelavić T, Barisić M, Drmic Hofman I, Boraska V, Vrdoljak E, Peruzović M, Hozo I, Puljiz Z, Terzić J: Microsatelite GT polymorphism in the toll-like receptor 2 is associated with colorectal cancer. Clin Genet 2006, 70:156-160.

19. Srivastava K, Srivastava A, Kumar A, Mittal B: Significant association between toll-like receptor gene polymorphisms and gallbladder cancer. Liver Int 2010, 30:1067-1072.

20. Nischalke HD, Coenen M, Berger C, Aldenhoff K, Müller T, Berg T, Krämer B, Körner C, Odenthal M, Schulze F, Grünhage F, Nattermann J, Sauerbruch T, 
Spengler U: The toll-like receptor 2 (TLR2) -196 to -174 del/ins polymorphism affects viral loads and susceptibility to hepatocellular carcinoma in chronic hepatitis C. Int J Cancer 2011, doi:10.1002/ijc.26143.

21. Egan MF, Straub RE, Goldberg TE, Yakub I, Callicott JH, Hariri AR, Mattay VS, Bertolino A, Hyde TM, Shannon-Weickert C, Akil M, Crook J, Vakkalanka RK, Balkissoon R, Gibbs RA, Kleinman JE, Weinberger DR: Variation in GRM3 affects cognition, prefrontal glutamate, and risk for schizophrenia. Proc Natl Acad Sci USA 2004, 101:12604-12609.

22. Fedetz M, Matesanz F, Caro-Maldonado A, Fernandez O, Tamayo JA, Guerrero M, Delgado C, López-Guerrero JA, Alcina A: OAS1 gene haplotype confers susceptibility to multiple sclerosis. Tissue Antigens 2006, 68:446-449.

23. Solís-Añez E, Delgado-Luengo W, Borjas-Fuentes L, Zabala W, Arráiz N, Pineda L, Portillo MG, González-Ferrer S, Chacín JA, Peña J, Montiel C, Morales A, Rojas de Atencio A, Cañizales J, González R, Miranda LE, Abreu N, Delgado J: Molecular analysis of the GABRB3 gene in autistic patients: an exploratory study. Invest Clin 2007, 48:225-242.

24. Hunt R, Sauna ZE, Ambudkar SV, Gottesman MM, Kimchi-Sarfaty C: Silent (synonymous) SNPs: should we care about them? Methods Mol Biol 2009, 578:23-39.

25. Shen LX, Basilion JP, Stanton VP Jr: Single-nucleotide polymorphisms can cause different structural folds of mRNA. Proc Natl Acad Sci USA 1999, 96:7871-7876

26. Cartegni L, Chew SL, Krainer AR: Listening to silence and understanding nonsense: exonic mutations that affect splicing. Nat Rev Genet 2002, 3:285-298

27. Chamary JV, Parmley JL, Hurst LD: Hearing silence: non-neutral evolution at synonymous sites in mammals. Nat Rev Genet 2006, 7:98-108.

28. Diatchenko L, Slade GD, Nackley AG, Bhalang K, Sigurdsson A, Belfer I, Goldman D, Xu K, Shabalina SA, Shagin D, Max MB, Makarov SS, Maixner W: Genetic basis for individual variations in pain perception and the development of a chronic pain condition. Hum Mol Genet 2005, 14:135-143.

29. Etokebe GE, Knezević J, Petricević B, Pavelić J, Vrbanec D, Dembić Z: Singlenucleotide polymorphisms in genes encoding toll-like receptor $-2,-3,-4$, and -9 in case-control study with breast cancer. Genet Test Mol Biomarkers 2009, 13:729-734.

30. Hold GL, Smith MG, McLean MH, Berry S, McColl KE, Mowat A, El Omar EM: Innate immune response gene polymorphisms and their role in $\mathrm{H}$ pylori-induced gastric cancer. Gastroenterology 2006, 130:A61.

31. Hold GL, Rabkin CS, Gammon MD, Berry SH, Smith MG, Lissowska J, Risch HA, Chow WH, Mowat NA, Vaughan TL, El-Omar EM: CD14-159C/T and TLR9-1237T/C polymorphisms are not associated with gastric cancer risk in Caucasian populations. Eur J Cancer Prev 2009, 18:117-119.

32. Zhang H, Zhai Y, Hu Z, Wu C, Qian J, Jia W, Ma F, Huang W, Yu L, Yue W Wang Z, Li P, Zhang Y, Liang R, Wei Z, Cui Y, Xie W, Cai M, Yu X, Yuan Y, Xia X, Zhang X, Yang H, Qiu W, Yang J, Gong F, Chen M, Shen H, Lin D, Zeng YX, He F, Zhou G: Genome-wide association study identifies 1 p36.22 as a new susceptibility locus for hepatocellular carcinoma in chronic hepatitis B virus carriers. Nat Genet 2010, 42:755-758.

\section{Pre-publication history}

The pre-publication history for this paper can be accessed here: http://www.biomedcentral.com/1471-2407/12/57/prepub

doi:10.1186/1471-2407-12-57

Cite this article as: Junjie et al: The association between Toll-like receptor 2 single-nucleotide polymorphisms and hepatocellular carcinoma susceptibility. BMC Cancer 2012 12:57.

\section{Submit your next manuscript to BioMed Central and take full advantage of:}

- Convenient online submission

- Thorough peer review

- No space constraints or color figure charges

- Immediate publication on acceptance

- Inclusion in PubMed, CAS, Scopus and Google Scholar

- Research which is freely available for redistribution

Submit your manuscript at www.biomedcentral.com/submit
Biomed Central 